\title{
Anti-metastatic effect of rhodomyrtone from Rhodomyrtus tomentosa on human skin cancer cells
}

\author{
MALATEE TAYEH $^{1}$, SIRINUN NILWARANGOON ${ }^{1}$, \\ WILAWAN MAHABUSARAKUM ${ }^{2}$ and RAMIDA WATANAPOKASIN ${ }^{1}$ \\ ${ }^{1}$ Department of Biochemistry, Faculty of Medicine, Srinakharinwirot University, Bangkok 10110; \\ ${ }^{2}$ Department of Chemistry, Faculty of Science, Prince of Songkla University, Hat Yai, Songkhla 90112, Thailand
}

Received October 4, 2016; Accepted December 27, 2016

DOI: 10.3892/ijo.2017.3845

\begin{abstract}
This study focused on the inhibitory effect of rhodomyrtone, a bioactive compound isolated from the leaves of Rhodomyrtus tomentosa (Aiton) Hassk., on cancer metastasis in epidermoid carcinoma A431 cells and on the verification of the underlying related molecular mechanisms of this event. We demonstrated that rhodomyrtone at the subcytotoxic concentration $(0.5$ and $1.5 \mu \mathrm{g} / \mathrm{ml})$ exhibited pronounced inhibition of cancer metastasis by reducing cell migration, cell adhesive ability and cell invasion of A431 cells in a dose-dependent manner. Data demonstrated that rhodomyrtone could inhibit the focal adhesion kinase (FAK) and phosphorylation of protein kinase B (AKT), c-Raf, extracellular signal-regulated kinase 1/2 (ERK1/2) and p38 MAPK involved in the downregulation the enzyme activities and protein expression of matrix metalloproteinase-2 (MMP-2) and MMP-9. Moreover, we found that rhodomyrtone increased the expression of TIMP-1 and TIMP-2, which are inhibitors of MMP-9 and MMP-2, respectively. Rhodomyrtone also inhibited the expression of NF- $\kappa \mathrm{B}$ and phosphorylation of NF- $\kappa \mathrm{B}$ in a dosedependent manner. These results suggested that rhodomyrtone inhibited A431 cell metastasis by reducing MMP-2/9 activities and expression through inhibiting ERK1/2, p38 and FAK/ Akt signaling pathways via $\mathrm{NF}-\kappa \mathrm{B}$ activities. This finding suggested that rhodomyrtone may be a novel antimetastasis agent for treatment of skin cancer cells.
\end{abstract}

\section{Introduction}

Cancer metastasis is the major cause of death in most cancer patients. It is a complex cascade process, in which cancer cells detach from the primary tumor, migrate, adhere and invade through the basement membrane or extracellular

Correspondence to: Professor Ramida Watanapokasin, Department of Biochemistry, Faculty of Medicine, Srinakharinwirot University, Bangkok 10110, Thailand

E-mail: ramidawa@yahoo.com; ramidaw@g.swu.ac.th

Key words: rhodomyrtone, Rhodomyrtus tomentosa (Aiton) Hassk., skin cancer, metastasis, A431 cells, MMP-2, MMP-9, ERK1/2, NF-кB matrix (ECM), survive in the circulatory system, invade into distant secondary organs or tissues, and start to proliferate (1). During the metastatic process, proteolytic enzymes play critical roles in helping cancer cells to enter into the vascular and lymphatic systems and invading tissues at ectopic sites. Among all proteolytic enzymes, the members of matrix metalloproteinases (MMPs) are the main group of proteolytic enzyme that is involved in the tumor invasion, metastasis and angiogenesis. MMPs or matrixins are a group of zinc-dependent endopeptidase enzymes, that respond to ECM degradation and tumor cell invasion, metastasis and angiogenesis (2). MMP-2 (gelatinase A, $72 \mathrm{kDa}$ ) and MMP-9 (gelatinase B, $92 \mathrm{kDa}$ ) are the key enzymes in degradation of the ECM components of basal membrane and type IV collagen, a major component of the basement membrane. Activities of MMPs are controlled by their endogenous inhibitors, tissue inhibitors of metalloproteinases (TIMPs) such as TIMP-1 and TIMP-2, in cancer cells $(3,4)$. It was reported that when the balance of MMPs and TIMPs was disrupted, direct inhibition of MMPs and increase of TIMPs in cancer may be a particular attractive target for therapeutic intervention in tumor invasion and metastasis (5). Therefore, inhibition of MMP activity and expression is important for inhibiting cancer metastasis, which affects mortality in patients.

Mitogen-activated protein kinases (MAPKs) include extracellular signal-regulated kinase 1 and 2 (ERK1/2), c-Jun N-terminal kinase/stress-activated protein kinase (JNK/SAPK), and p38 MAPK, play an important regulatory role in cell growth, differentiation, apoptosis, and metastasis (6). AKT (also known as PKB) is also involved in multiple cellular processes such as cell growth, cell proliferation, angiogenesis and metastasis in various cancers (7). They have a central role in regulating the expression of MMPs (8-11). In addition, the expression of MMPs is also regulated by nuclear-factor- $\kappa \mathrm{B}(\mathrm{NF}-\kappa \mathrm{B})$ and the activator protein 1 (AP-1) as the MMP gene has an $\mathrm{NF}-\kappa \mathrm{B}$ and AP-1 binding site in its promoter region $(12,13)$. Inhibition of the MAPK and PI3K/Akt pathways as well as NF- $\kappa \mathrm{B}$ and AP-1 activities may lead to potential prevention of cancer cell proliferation, invasion, and metastasis.

Traditionally, Rhodomyrtus tomentosa (Aiton) Hassk., the family myrtaceae, has been used for anti-inflamation, to treat diarrhea, gastrointestinal, urinary tract infections and 
antiseptic wash for wounds $(14,15)$. It is native to Southeast Asia and is a troublesome invader of native plant communities in Florida (16). Rhodomyrtone is a pure compound, isolated from Rhodomyrtus tomentosa leaves. Previous studies have shown that rhodomyrtone displays antibacterial activity against a wide range of gram-positive bacteria such as Bacillus subtilis, Enterococcus faecalis, Staphylococcus aureus, Staphylococcus epidermidis, Streptococcus spp., and methicillin-resistant Staphylococcus aureus (MRSA) (17-21). Moreover, rhodomyrtone stimulated pro- and anti-inflammatory cytokine responses (22) and reduced hyperproliferation and abnormal differentiation of $\mathrm{HaCaT}$ cells (23). However, the anti-metastatic activity of rhodomyrtone on cancer cells has not yet been reported.

Non-melanoma skin cancer (NMSC) is the most common cancer affecting white-skinned individuals and the incidence is increasing worldwide. There are two main types of NMSC including the basal cell carcinomas (BCCs) and squamous cell carcinomas (SCCs) $(24,25)$. SCC is the second most common skin cancer, accounting for $\sim 20 \%$ of NMSC cases. It is more common in older people. The main risk factor for skin cancer is exposure to UV radiation, which causes cellular damage $(26,27)$. Current treatments of SCCs consist of surgery, photodynamic therapy, radiation therapy, chemotherapy or combination therapy, but these treatments are unsatisfactory. Thus, it is necessary to search for a new effective therapeutic agent to treat SCCs.

In this study, we investigated the inhibitory effect of rhomyrtone on cancer metastasis in A431 cells. It was demonstrated that rhodomyrtone effectively inhibits cell migration, invasion and adhesion in human epidermoid carcinoma A431 cells.

\section{Materials and methods}

Chemical and antibodies. Rhodomyrtone was obtained from Dr Wilawan Mahabusarakum, Department of Chemistry, Faculty of Science, Prince of Songkla University, Songkhla, Thailand. It was dissolved in dimethylsulfoxide (DMSO). MTT (3-(4,5-dimethyl-2,5-diphenyl tetrazolium bromide), DMSO and trypan blue were purchased from Sigma-Aldrich Corp. (St. Louis, MO, USA). Dulbecco's modified Eagle's medium (DMEM) was purchased from Gibco/BRL (Gaithersburg, MD, USA). Matrigel was purchased from BD Biosciences (Bedford, MA, USA). Immobilon Western Chemiluminescent HRP substrate was purchased from Merck Millipore Corp. (Merck KGA, Darmstadt, Germany). The protein assay kit and Coomassie Brilliant Blue R-250 were obtained from Bio-Rad Labs (Hercules, CA, USA). Antibodies (Abs) for immunoblotting analysis including rabbit monoclonal Abs against matrix metalloproteinase-2 (MMP-2), MMP-9, tissue inhibitor of metalloproteinase-1 (TIMP-1), TIMP-2, RAS, growth factor receptor-bound protein-2 (GRB2), focal adhesion kinase (FAK), p-FAK (Try397), pPDK1 (Ser241), p-cRaf, extracellular signal regulation kinase 1/2 (ERK1/2), p-ERK1/2, p38, p-p38, c-Jun N-terminal kinase 1/2 (JNK1/2), pJNK1/2, AKT, pAKT (Ser473) pAKT (Thr308), c-Fos, c-Jun, p-cJun, nuclear factor $\kappa \mathrm{B}(\mathrm{NF}-\kappa \mathrm{B}), \mathrm{p}-\mathrm{NF}-\kappa \mathrm{B}$ and anti-mouse immunoglobulin $\mathrm{G}$ and anti-rabbit immunoglobulin $\mathrm{G}$ horseradish peroxidase-conjugated secondary antibodies were obtained from Cell Signaling Technology, Inc. (Danvers, MA, USA), and mouse monoclonal Abs against $\beta$-actin was obtained from Merck Millipore Corp. (Merck KGaA).

Cell line and cell culture. The human epidermoid carcinoma cell line (A431) was obtained from the American Type Culture Collection (ATCC, Manassas, VA, USA). A431 cells were maintained as a monolayer in DMEM (Gibco Life Technologies, Carlbad, CA, USA) supplemented with 10\% FBS (GE Healthcare Life Science, Little Chalfont, UK), 100 U/ml penicillin and $100 \mu \mathrm{g} / \mathrm{ml}$ streptomycin (GE Healthcare Life Science, Inc.) at $37^{\circ} \mathrm{C}$ in a humidified $5 \% \mathrm{CO}_{2}$.

Cell viability analysis. A431 cells $\left(7 \times 10^{3}\right.$ cell/well) were seeded in a 96-well plate for $24 \mathrm{~h}$. Then cells were treated with rhodomyrtone at various concentrations $(0,0.5,1.5,3,5$, 10 and $15 \mu \mathrm{g} / \mathrm{ml}$ ) for $24 \mathrm{~h}$. After treatment $0.5 \mathrm{mg} / \mathrm{ml}$ of MTT solution was added to each well and incubated for $2 \mathrm{~h}$ at $37^{\circ} \mathrm{C}$. The supernatant was removed and DMSO was added to each well to solubilize water insoluble purple formazan crystals. The absorbance was measured using a Epoch ${ }^{\mathrm{TM}}$ Microplate Spectrophotometer at $570 \mathrm{~nm}$ and survival percentage (\%) was calculated relative to the control.

In vitro migration and invasion assay. Cells were pretreated with $0,0.5,1.5$ and $3 \mu \mathrm{g} / \mathrm{ml}$ rhodomyrtone for $24 \mathrm{~h}$. The cells were harvested and seeded to the upper chamber of the Transwell insert [polyethylene terephthalate (PET) filters, Merck Millipore Corp.] at $10^{4}$ cell/well in serum-free medium. The lower chambers were filled with FBS medium as chemoattractant, and thereafter these Transwell inserts were incubated for $24 \mathrm{~h}$ at $37^{\circ} \mathrm{C}$ in $5 \%(\mathrm{v} / \mathrm{v}) \mathrm{CO}_{2}$. For invasion assay, the Transwell insert was coated with $30 \mu \mathrm{g}$ Matrigel (BD Biosciences, MA, USA) and lower chambers were filled with FBS medium. After incubation, the cells were removed with a cotton swab and those on the lower surface of the membrane were fixed with methanol and stained with $0.5 \%$ crystal violet. Cells that migrate through the membrane were viewed and photographed under an inverted microscope (Olympus). The percentage of the migratory cells for each treatment was calculated by NIH ImageJ software, version 1.46r.

Cell-matrix adhesion assay. Cells at $2 \times 10^{5}$ cells/well were pretreated with various concentrations of rhodomyrtone $(0,0.5,1.5$ and $3 \mu \mathrm{g} / \mathrm{ml})$ for $24 \mathrm{~h}$, then $1 \times 10^{4}$ cells/well were seeded into the Matrigel-coated 96-well plate for $1 \mathrm{~h}$. The non-adherent cells were then removed with PBS and the adherent cells were reacted with $0.5 \mathrm{mg} / \mathrm{ml}$ of MTT solution at $37^{\circ} \mathrm{C}$ for $2 \mathrm{~h}$. After that $100 \mu 1$ of DMSO was added to each well to solubilize water insoluble purple formazan crystals. The absorbance was measured at $570 \mathrm{~nm}$ using a microplate reader. The percentage (\%) of cell adhesion was calculated relative to the control.

Gelatin zymography. Cells were treated with various concentrations of rhodomyrtone $(0,0.5,1.5$ and $3 \mu \mathrm{g} / \mathrm{ml})$ for $24 \mathrm{~h}$, the conditioned media were collected and mixed with non-reducing sample buffer. Samples were separated by SDS-PAGE containing $0.1 \%$ gelatin. After electrophoresis, gels were washed with $2.5 \%$ Triton X-100 for 30 min, 3 times 


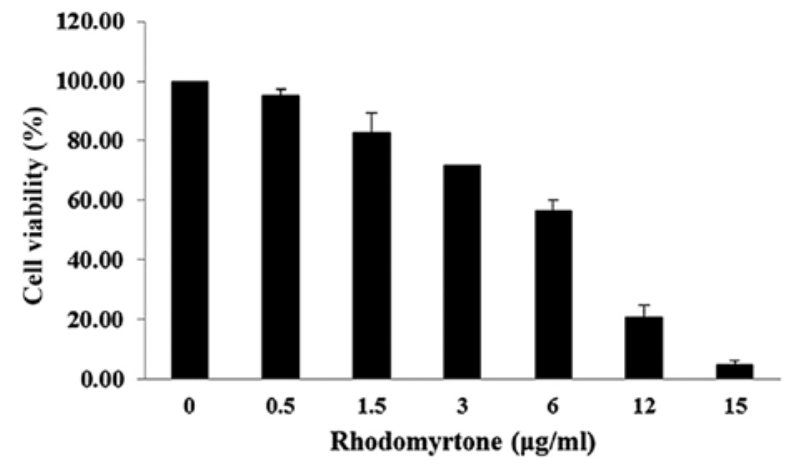

Figure 1. The effect of rhodomyrtone on cell proliferation at different concentrations for $24 \mathrm{~h}$. The subtoxic concentration range of rhodomyrtone that resulted in $>80 \%$ cell viability was selected for subsequent studies. Values represent mean $\pm \mathrm{SD}$ in three independent experiments.

and incubated in zymogram incubation buffer $(50 \mathrm{mM}$ Tris-HCl, pH 7.6, $10 \mathrm{mM} \mathrm{CaCl}_{2}, 50 \mathrm{mM} \mathrm{NaCl}, 0.05 \%$ Brij35) for $48 \mathrm{~h}$ at $37^{\circ} \mathrm{C}$. Then the gels were rinsed with distilled water and stained with Coomassie Brilliant Blue R-250. The bands of gelatinolytic activity were quantified using NIH ImageJ software, version $1.46 \mathrm{r}$.

Western blot analysis. Cells were lysed in RIPA buffer (50 mM Tris-HCl, pH 7.5, 5 mM EDTA, $250 \mathrm{mM} \mathrm{NaCl,} \mathrm{0.5 \%}$ Triton X-100), after treatment with $0,0.5,1.5$ and $3 \mu \mathrm{g} / \mathrm{ml}$ of rhodomyrtone. Total proteins were separated by SDS-PAGE and transferred onto a PVDF membrane (Millipore Corp., Billerica, MA, USA). After protein transferring, the membranes were subsequently blocked with $5 \%$ non-fat milk for $1 \mathrm{~h}$ at room temperature to block non-specific binding. Then membranes were incubated with specific primary antibody against MMP-2, MMP-9, TIMP-1, TIMP-2, RAS, GRB2, FAK, p-FAK (Try397), pPDK1 (Ser241), p-cRaf, ERK1/2, p-ERK1/2, p38, p-p38, JNK1/2, pJNK1/2, AKT, pAKT (Ser473) pAKT (Thr308), c-Fos, c-Jun, p-cJun, NF- $\mathrm{B}, \mathrm{p}-\mathrm{NF}-\kappa \mathrm{B}$ and $\beta$-actin at $4^{\circ} \mathrm{C}$, overnight. Subsequently, membranes were incubated with anti-mouse or anti-rabbit antibody conjugated with horseradish peroxidase (Cell Signaling Technology) for $1 \mathrm{~h}$ at room temperature. The protein bands were detected by chemiluminescence using enhanced chemiluminescence reagent (ECL) (Millipore) and exposed to CCD camera (Biotek Instruments, Winooski, VT, USA). The quantitative results for the protein of interest were expressed as relative to an internal housekeeping control such as $\beta$-actin.

Statistical analysis. To compare the data from different treatments, one-way ANOVA was used. All data presented were obtained from at least three independent experiments and were presented as mean \pm standard deviation (SD). A p-value of 0.05 was taken as minimum basis for assigning significance. The statistical analyses were performed using SPSS 17.0 software.

\section{Results}

Effect of rhodomyrtone on A431 cell proliferation. The effect of rhodomyrtone on A431 cell viability was analyzed by MTT assay. The viability of A431 cells treated with rhodomyrtone under different concentrations $(0,0.5,1.5,3,5,10$ and $15 \mu \mathrm{g} / \mathrm{ml})$ for $24 \mathrm{~h}$ as shown in Fig. 1. The result demonstrated that

\section{A} Rhodomyrtone $(\mu \mathrm{g} / \mathrm{ml})$
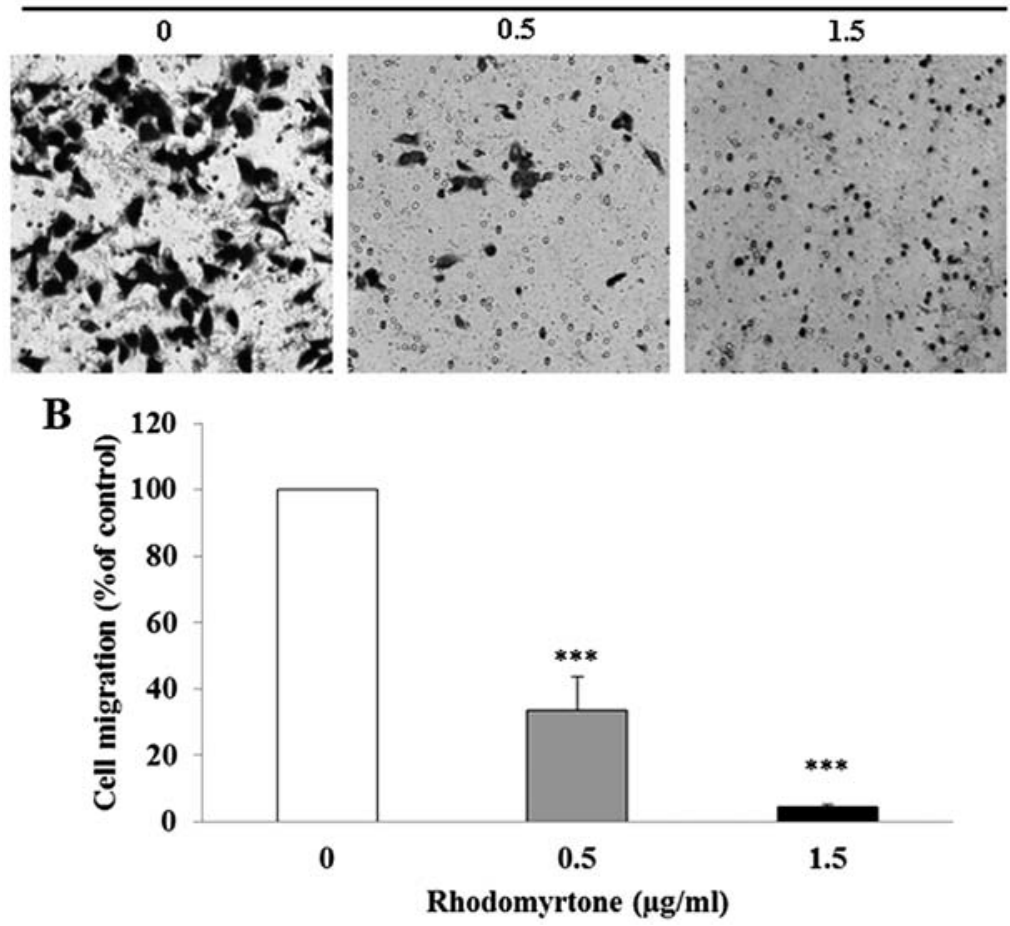

Figure 2. Effect of rhodomyrtone on A431 cell migration. Rhodomyrtone inhibited cell migration as tested by Transwell chamber assay. The migratory cells were stained with crystal violet and photographed (x40 magnification). Data are presented as mean \pm SD of three independent experiments. ${ }^{* * *}$ p $<0.001$ compared with the control group. 
A Rhodomyrtone $(\mu \mathrm{g} / \mathrm{ml})$

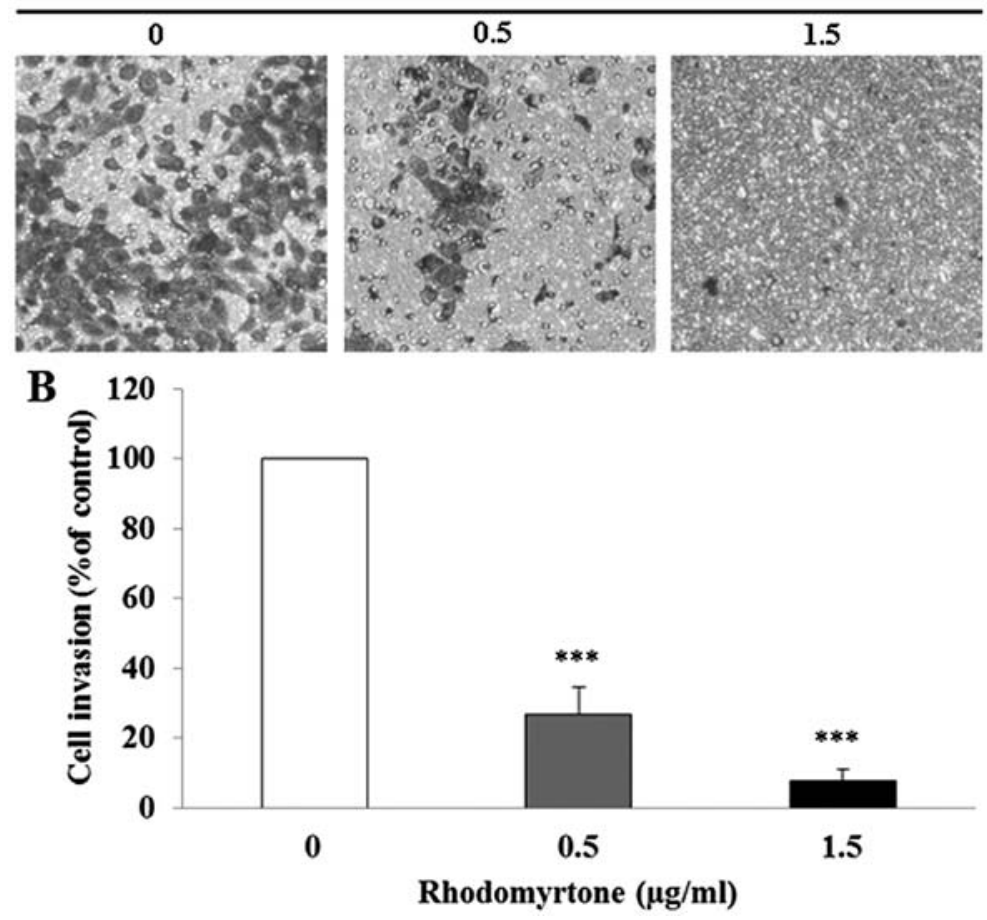

Figure 3. Effects of rhodomyrtone on A431 cell invasion. A431 cells treated with or without rhodomyrtone 24 h on Matrigel-coated filter (pore size, $8 \mu$ m) in Boyden chamber. (A) The invaded cells were stained with crystal violet and photographed (x40 magnification). (B) The invasion rate is presented as a percentage of the control. Data are presented as mean \pm SD of three independent experiments. ${ }^{* * *}$ p $<0.001$ compared with the untreated control.

rhodomyrtone inhibited A431 cell viability in a time- and dosedependent manner. At the high concentrations, rhodomyrtone significantly inhibited cell proliferation of A431 cells while at lower concentrations no significant effect was observed. The non-cytotoxic concentration and subcytotoxic concentration $(<1.5 \mu \mathrm{g} / \mathrm{ml}$ showing $>80 \%$ cell proliferation) was selected for the subsequent experiment.

Effect of rhodomyrtone on A431 cell migration and invasion. The effect of rhodomyrtone on A431 cell migration and invasion was determined by Transwell chamber assay. After A431 cells wre treated with rhodomyrtone at 0.5 and $1.5 \mu \mathrm{g} / \mathrm{ml}$ for $24 \mathrm{~h}$, rhodomyrtone significantly reduced cell migration in a dose-dependent manner (Fig. 2; p<0.001). The percentage of cell migration was $33.6 \pm 9.9$ and $4.4 \pm 0.8 \%$ after treatment with 0.5 and $1.5 \mu \mathrm{g} / \mathrm{ml}$ rhodomyrtone, respectively. Moreover, we found that rhodomyrtone significantly inhibited the invasion of A431 cell through Matrigel-coated filter in a dose-dependent manner ( $\mathrm{p}<0.001)$. Exposure of A431 cells to 0.5 and $1.5 \mu \mathrm{g} / \mathrm{ml}$ rhodomyrtone inhibited 73.2 and $92.3 \%$ of cell invasion, respectively (Fig. 3). These results revealed that rhodomyrtone markedly inhibits migration and invasion of A431 cells.

Effect of rhodomyrtone on adhesion ability of A431 cells. We examined the effect of rhodomyrtone on adhesion ability of A431 cells to Matrigel. The result demonstrated that the adhesive capacities of A431 cells to Matrigel were significantly decreased after treatment with 0.5 and $1.5 \mu \mathrm{g} / \mathrm{ml}$ rhodomyrtone when compared to the untreated control group as shown in Fig. 4.

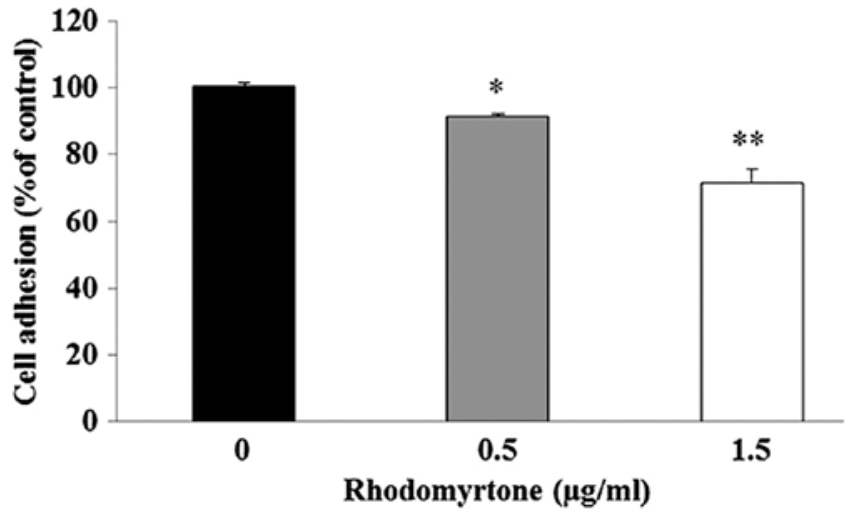

Figure 4. Effect of rhodomyrtone on adhesion ability of A431 cells. Adhesion of A431 cells to Matrigel were markedly inhibited by rhodomyrtone at concentration of 0.5 and $1.5 \mu \mathrm{g} / \mathrm{ml}$ as compared with control group. Data are presented as mean \pm SD of three independent experiments. ${ }^{*} \mathrm{p}<0.05,{ }^{* *} \mathrm{p}<0.01$ compared with the control group.

Effect of rhodomyrtone on MMP-9 and MMP-2 activities. To determine the possible mechanism of rhodomyrtone to inhibit cell migration and invasion, we investigated the activity of MMP-2 and MMP-9 in culture media of A431 cells using gelatin zymography. After treatment with 0.5 and $1.5 \mu \mathrm{g} /$ $\mathrm{ml}$ of rhodomyrtone for $24 \mathrm{~h}$, the conditioned medium was collected and MMP activity was estimated from densitometric analysis. The result showed rhodomyrtone reduced MMP-2 and MMP-9 activities in a dose-dependent manner (Fig. 5). MMP-2 activity was reduced by 53.5 and $37.8 \%$ and MMP-9 activity was reduced by 51.1 and $30.3 \%$ upon treatment with 
$\mathbf{A}$

\begin{tabular}{ccc}
\multicolumn{3}{c}{ Rhodomyrtone $(\mu \mathrm{g} / \mathrm{ml})$} \\
\hline 0 & 0.5 & 1.5
\end{tabular}

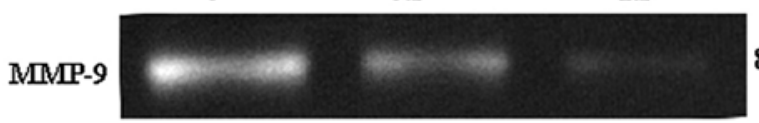
$85 \mathrm{kDa}$

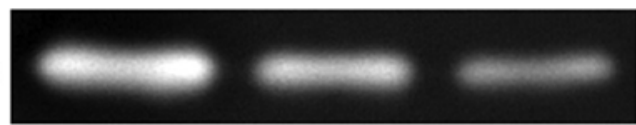

$64 \mathrm{kDa}$

B

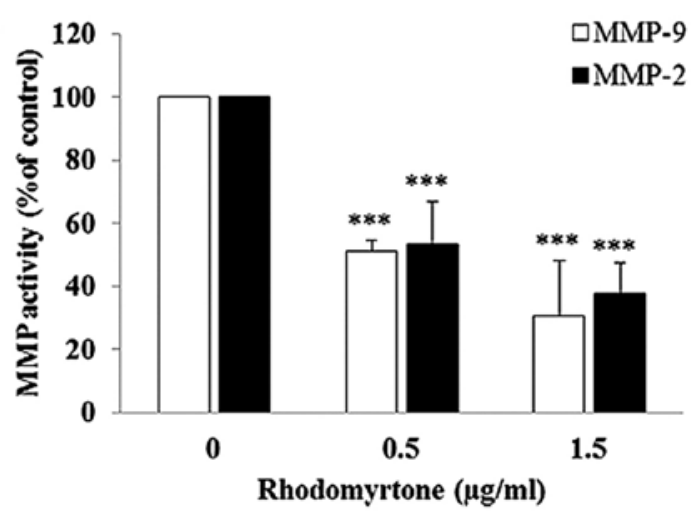

Figure 5. Effect of rhodomyrtone on MMP-9 and MMP-2 activities. (A) Cells were treated with the 0.5 and $1.5 \mu \mathrm{g} / \mathrm{ml}$ of rhodomyrtone for $24 \mathrm{~h}$. The conditioned media were collected and MMP-2 and MMP-9 activities were examined by gelatin zymography analysis. (B) The activities of MMP-2 and MMP-9 were quantified by using NIH ImageJ. Data are presented as mean \pm SD of three independent experiments. ${ }^{* * *} \mathrm{p}<0.001$ compared with the untreated group.

$\mathbf{A}$
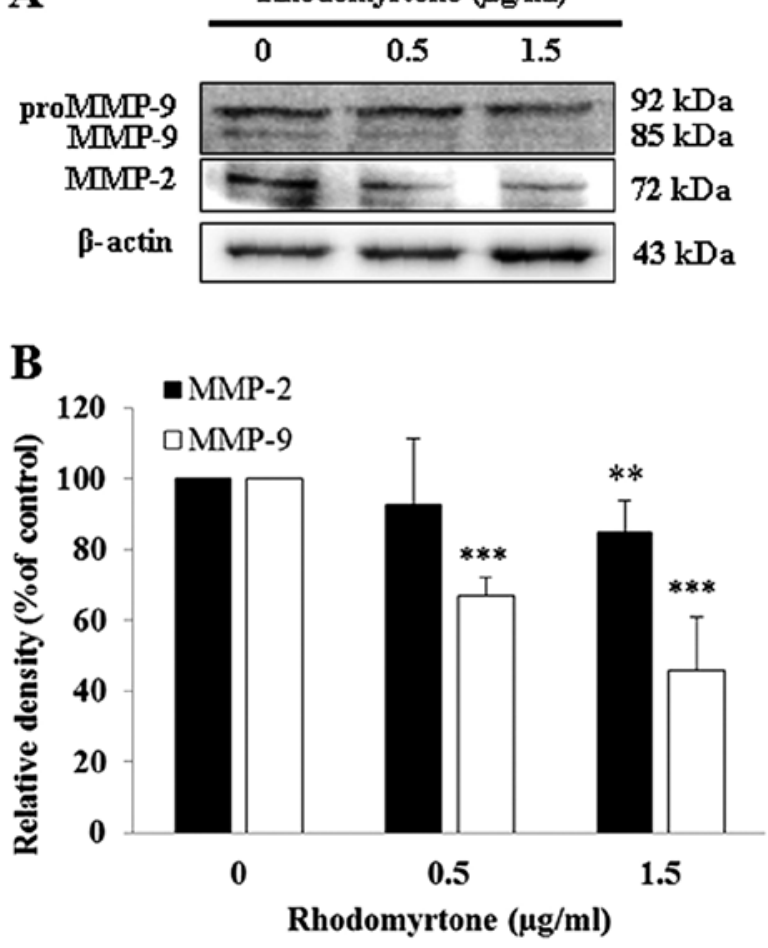

0.5 and $1.5 \mu \mathrm{g} / \mathrm{ml}$ of rhodomyrtone, respectively. The results indicated that rhodomyrtone inhibited MM-2 and MMP-9 activities in A431 cells.

Effects of rhodomyrtone on MMP-2, MMP-9, TIMP-1 and TIMP-2 expression in A431 cells. MMP-2 and MMP-9 are involved in the degradation of ECM and are essential to the cell migration and invasion during metastasis. The effects of rhodomyrtone on MMP-2 and MMP-9 expression were detected by western blot analysis. As shown in Fig. 6A and B, rhodomyrtone suppressed the expression of MMP-2 and MMP-9 in a dose-dependent manner. Inhibition of MMP-2 was $\sim 15.3 \%$ upon treatment with $1.5 \mu \mathrm{g} / \mathrm{ml}$ rhodomyrtone and MMP-9 was $~ 33.1$ and $54.2 \%$ with 0.5 and $1.5 \mu \mathrm{g} / \mathrm{ml}$ rhodomyrtone, respectively. Furthermore, we demonstrated that rhodomyrtone markedly increased TIMP-1 and TIMP-2 protein expression upon treatment with 0.5 and $1.5 \mu \mathrm{g} / \mathrm{ml}$ rhodomyrtone for $24 \mathrm{~h}$ (Fig. 6C and D). TIMP-1 and TIMP-2 are known to be the specific endogenous inhibitors of MMPs.

Effect of rhodomyrtone on GRB2, RAS, MAPK signaling pathway and p-cRaf expression. We determined the mechanisms of rhodomyrtone for anti-metastatic effects on A431 cells. GRB2, RAS, p-cRaf and MAPK expression were investigated in A431 cells. The results showed that rhodomyrtone significantly reduced the phosphorylation of cRaf, ERK $1 / 2$ and p38 in a dose-dependent manner, but no significant alterations were observed in GRB2, RAS, ERK1/2 and p38 as shown in Fig. 7.
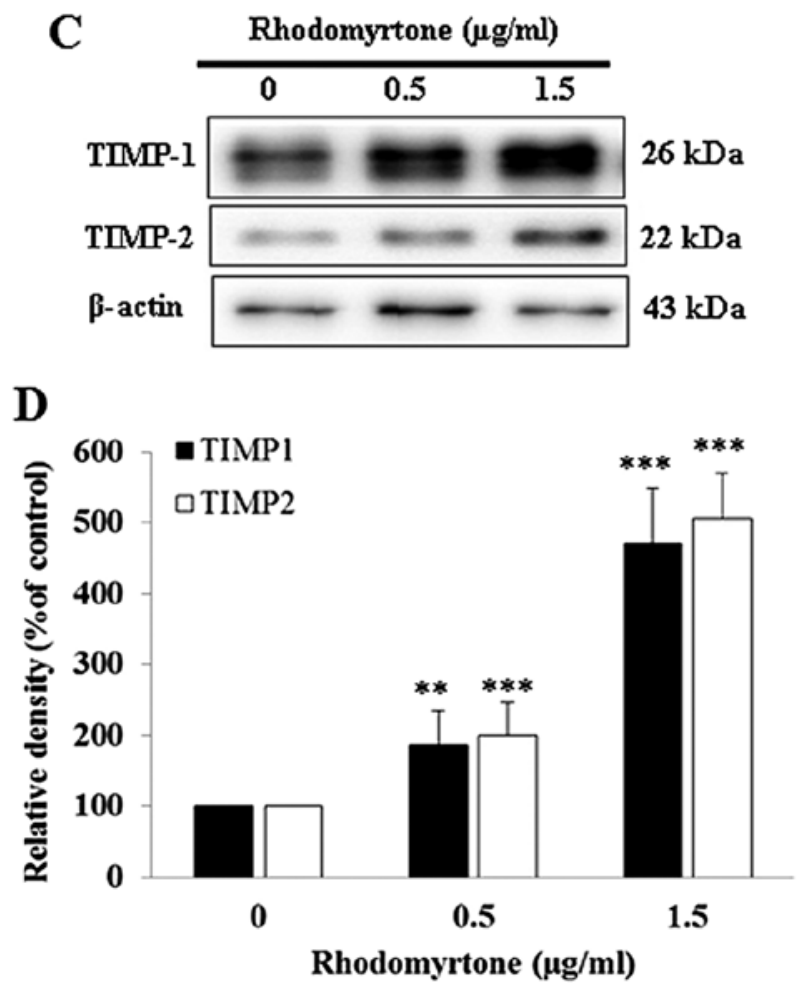

Figure 6. Rhodomyrtone inhibits MMPs expression and increases the protein level of TIMPs in A431 cells. (A and B) Cell were treated with 0.5 and $1.5 \mu \mathrm{g} /$ $\mathrm{ml}$ rhodomyrtone for $24 \mathrm{~h}$, and the protein expression of MMP-2 and MMP-9 were detected using specific antibodies and $\beta$-actin was used as loading control. (C and D) The protein level of TIMP-1 and TIMP-2 were also detected when the cells were treated with 0.5 and $1.5 \mu \mathrm{g} / \mathrm{ml}$ rhodomyrtone for $24 \mathrm{~h}$, and $\beta$-actin was used as loading control. Data are presented as mean \pm SD of three independent experiments. ${ }^{*} \mathrm{p}<0.05,{ }^{* *} \mathrm{p}<0.01,{ }^{* * * *} \mathrm{p}<0.001 \mathrm{compared}$ with the untreated group. 

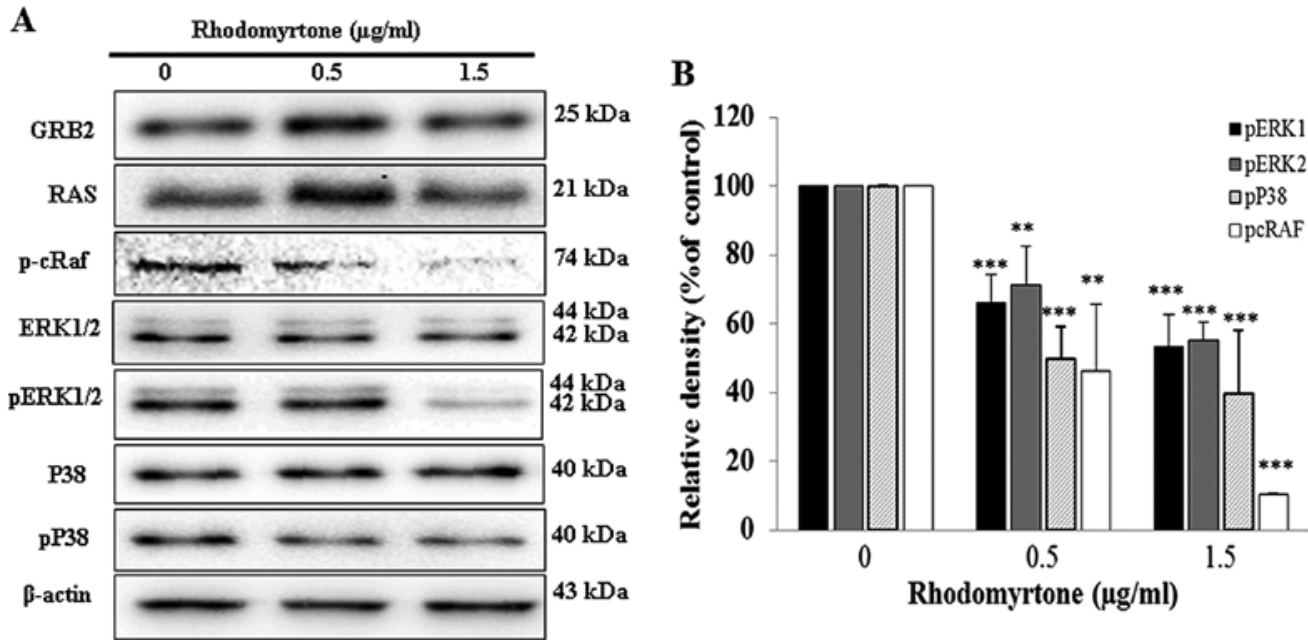

Figure 7. Effect of rhodomyrtone on GRB2, RAS, p-cRaf and MAPK signaling pathway proteins expression. Cell were treated with 0.5 and $1.5 \mu \mathrm{g} / \mathrm{ml} \mathrm{rho}-$ domyrtone for $24 \mathrm{~h}$, and the protein expression of GRB2, RAS, p-cRaf, ERK1/2,pERK1/2, p38 and pp38 were detected with western blotting analysis using specific antibodies and $\beta$-actin was used as loading control. The values are presented as mean \pm SD of three independent experiments.** $\mathrm{p}<0.01,{ }^{* * * *} \mathrm{p}<0.001$ compared with the untreated group.
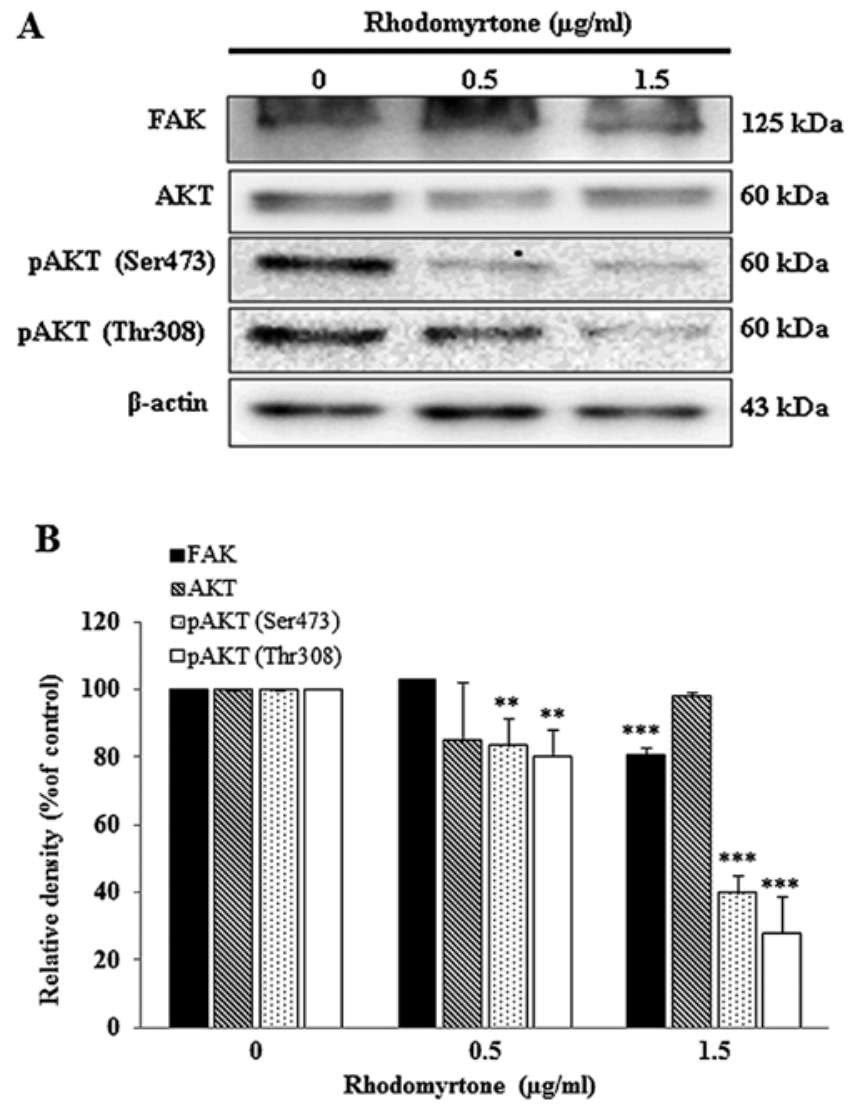

Figure 8. Effect of rhodomyrtone on FAK and AKT signaling pathway. Cells were treated with 0.5 and $1.5 \mu \mathrm{g} / \mathrm{ml}$ rhodomyrtone for $24 \mathrm{~h}$, and the protein expression of FAK, AKT, pAKT (Ser473) and pAKT (Thr308) were detected by western blot analysis using specific antibodies and $\beta$-actin was used as loading control. The values are presented as mean \pm SD of three independent experiments. ${ }^{* *} \mathrm{p}<0.01,{ }^{* * *} \mathrm{p}<0.001$ compared with the untreated group.

Effect of rhodomyrtone on FAK and AKT signaling pathway. To determine whether rhodomyrtone inhibits A431 cells migration and invasion via FAK/PI3K/Akt, cells were treated
$\mathbf{A}$
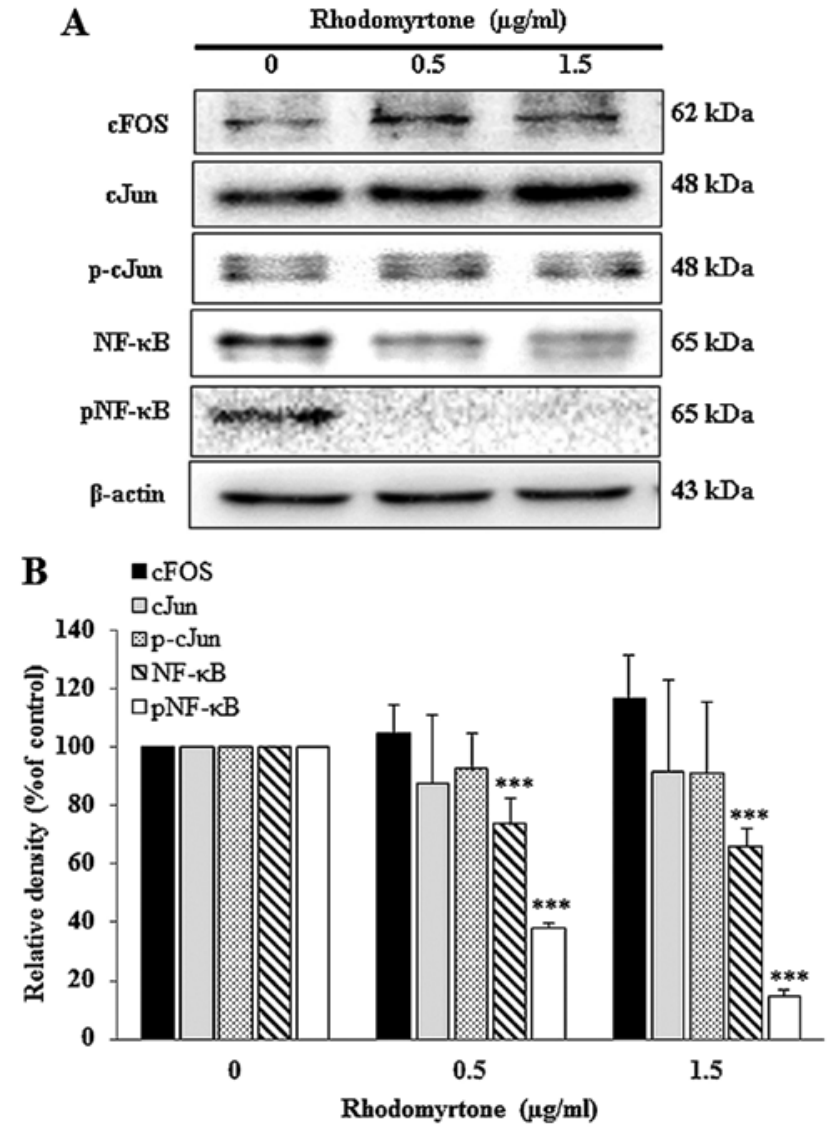

Figure 9. Effect of rhodomyrtone on AP-1 and NF- $\mathrm{BB}$ protein expression. Cells were treated with 0.5 and $1.5 \mu \mathrm{g} / \mathrm{ml}$ rhodomyrtone for $24 \mathrm{~h}$, and the protein expression of cFos, cjun, p-cjun (components of transcription factor $\mathrm{AP}-1), \mathrm{NF}-\kappa \mathrm{B}$ and $\mathrm{pNF}-\kappa \mathrm{B}$ were investigated by western blot analysis using specific antibodies and $\beta$-actin was used as loading control. The values are presented as mean $\pm \mathrm{SD}$ of three independent experiments. ${ }^{* * *} \mathrm{p}<0.001 \mathrm{com}-$ pared with the untreated group.

with 0.5 and $1.5 \mu \mathrm{g} / \mathrm{ml}$ rhodomyrtone for $24 \mathrm{~h}$. FAK, AKT, pAKT (Ser473) and pAKT (Thr308) were detected by western blot analysis. Fig. 8A showed rhodomyrtone could suppress 


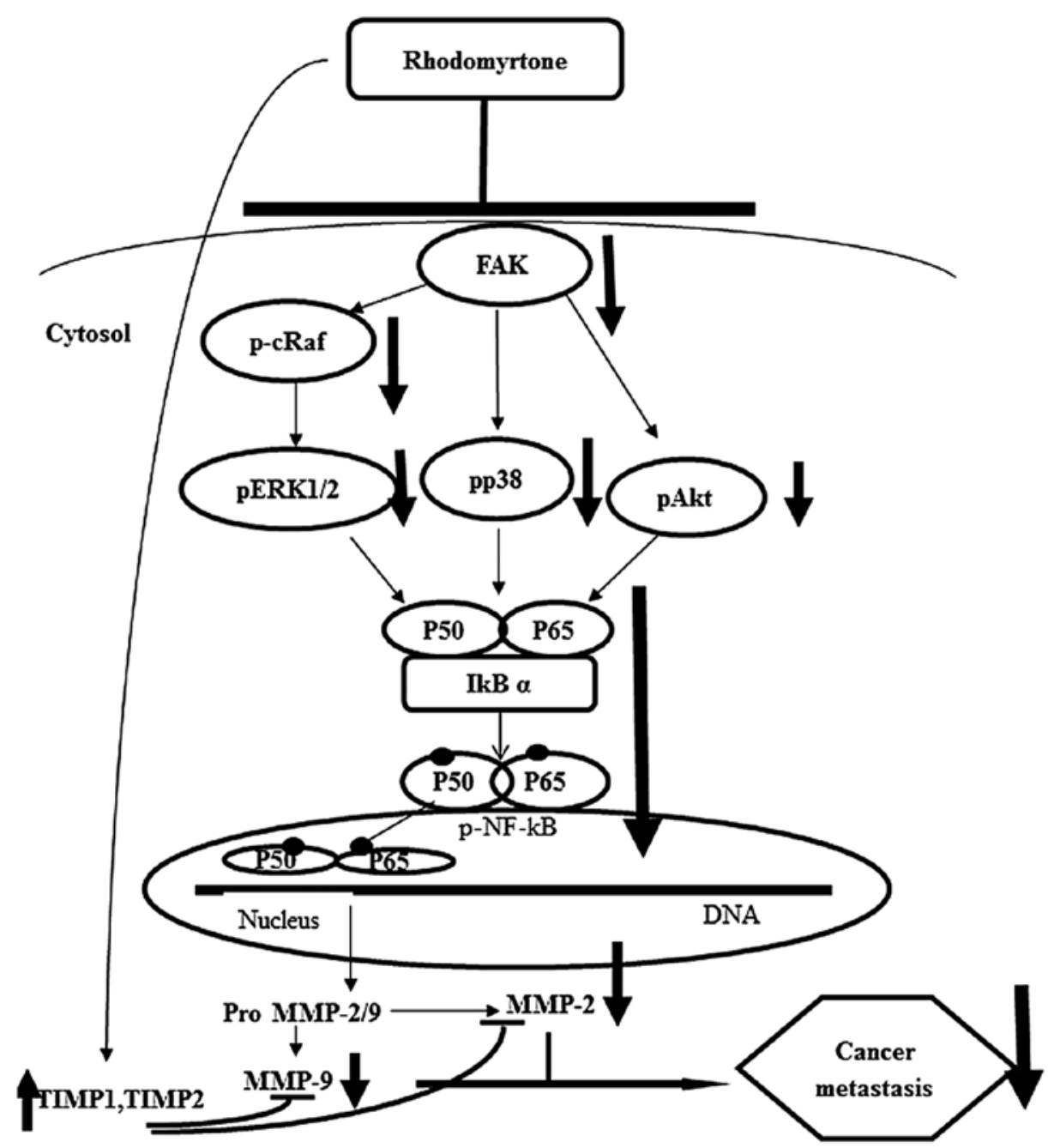

Figure 10. Rhodomyrtone inhibits cancer metastasis of A431 cells by suppressing MMP-2 and MMP-9 activities and protein expression and induces TIMP-1 and TIMP-2. Anti-metastatic effect of rhodomyrtone on A431 cells in human epidermoid carcinoma is through the inhibition of Raf/ERK, p38 MAPK and FAK/Akt signaling pathways via NF- $\kappa \mathrm{B}$ activities.

FAK and the phosphorylation of AKT. The quantitative results showed that rhodomyrtone significantly inhibited the FAK and the phosphorylation of AKT in a dose- and time-dependent manner (Fig. 8B).

Effect of rhodomyrtone on $A P-1$ and $N F-\kappa B$ protein expression. The inhibitory effect of rhodomyrtone on transcription factor NF- $\kappa$ B and AP-1 in A431 cells were investigated by western blotting. Data demonstrated that A431 cells treated with rhodomyrtone significantly decreased the level of NF- $\mathrm{KB}$ and pNF- $\kappa \mathrm{B}$ expression in a dose-dependent manner (Fig. 9), but, there was no change in the expression of cFos, cJun and p-cJun (components of transcription factor AP-1) under the same conditions. The results indicated that rhodomyrtone significantly inhibited NF- $\mathrm{\kappa B}$ protein expression.

\section{Discussion}

Therapeutic agents to prevent development of metastases are an urgent therapeutic need. Present cancer chemotherapy is mainly targeted on primary tumors but the late stage patient survival has improved very little. We demonstrated that rhodomyrtone could inhibit A431 cell proliferation in a dosedependent manner (Fig. 1). Rhodomyrtone at non-cytotoxic concentration and subcytotoxic concentration $(0-1.5 \mu \mathrm{g} / \mathrm{ml})$ significantly reduced A431 cell migration and cell invasion by Transwell chamber (Fig. 2) and the Matrigel-coated Boyden chamber assay in a dose-dependent manner (Fig. 3). Rhodomyrtone also exhibited the anti-adhesion in A431 cells on Matrigel as shown in Fig. 4, These results indicated that rhodomyrtone inhibits cell metastasis of A431 human skin cancer independent of cell cytotoxicity. Consistent with Lee et al who showed andrographolide at low-cytotoxic concentration inhibits the invasion and migration of human non-small cell lung cancer A549 cells (28). Thus, rhodomyrtone might be used as a chemotherapeutic agent for cancer treatment in skin cancer in the future.

This study showed that rhodomyrtone significantly inhibited MMP-2 and MMP-9 protein expression as well as MMP-2 and MMP-9 enzyme activity but increased TIMP-1 and TIMP-2 expression. Overexpression of MMP-2 and MMP-9 are involved in cancer angiogenesis, cancer invasion and metastasis. Thus inhibition of MMP-2 and MMP-9 expression or enzyme activity provide early targets of cancer metastasis 
prevention (29-31). Reduction of MMP-2 and MMP-9 activities and protein expression have been shown to inhibit cell migration and invasion in various types of cancer cells (32-38). Moreover, Wang et al reported that upregulation of TIMP-1 could inhibit activity of MMP-2 and suppressed HepG2 and MHCC97L metastasis (34). In addition, invasion of hepatocellular carcinoma was inhibited by Chrysanthemum indicum ethanolic extract via the imbalance of MMPs and TIMPs (35). This finding supported possible anti-metastatic mechanism of rhodomyrtone in skin cancer.

Several studies have demonstrated the role of the MAPK and PI3K/AKT pathway in regulating MMPs expression $(9,39)$. In this study, we found that rhodomyrtone significantly inhibited the cRaf, ERK1/2 and p38 phosphorylation in A431 cells in a dose-dependent manner (Fig. 7). Likewise, previous reports showed the inhibition of MMP-2 and MMP-9 expression in cancer cells via ERK1/2 pathway $(9,32,39,40)$. Chen et $a l$ and Chien et al showed the expression of MMP-2 and MMP-9 were regulated by p38 $\alpha$ MAPK pathway $(41,42)$. In addition, we showed that rhodomyrtone inhibited FAK and the phosphorylation of AKT (Ser473) and AKT (Thr308) in A431 cells. Previous studies showed the inhibition of cell invasion and migration of human non-small cell lung cancer through FAK/PI3K/AKT signaling pathway (43). Qin et al also showed the inhibition of breast cancer cell invasion by suppressing the expression of MMP-2 and MMP-9 through the integrin $\beta 1 /$ FAK/PI3K/AKT/ $\beta$-catenin signaling by excisanin A (44). The promoter regions of MMP genes show remarkable conservation of regulatory elements, including AP-1 and NF- $\mathrm{KB}(12,13)$. $\mathrm{NF}-\mathrm{\kappa B}$ is constitutively activated in various types of cancer, including breast cancer and has been shown to contribute to the development and progression of tumors including HCC cells (45). Herein, we found that rhodomyrtone significantly inhibited NF-kB protein expression (Fig. 9). Similarly to the previous result demonstrated that tomatidine inhibited the invasion of A549 cells by reducing MMPs expression via ERK and AKT signaling pathways and NF- $\mathrm{BB}$ activity (46). Consistent with Lu et al showed the inhibition of migration and invasion in melanoma cells by $\alpha$-solanine via JNK, PI3K/ AKT and NF- $\kappa B$ pathway (47).

In conclusion, we demonstrated that rhodomyrtone inhibited cell migration, adhesion and invasion of A431 cells by suppressing MMP-2 and MMP-9 activities and MMP-2 and MMP-9 protein expression. Furthermore, we showed the mechanism of anti-metastatic effect of rhodomyrtone on A431 cells through the inhibition of Raf/ERK, p38 MAPK and FAK/Akt signaling pathways via NF- $\mathrm{KB}$ activities (Fig. 10). These findings reveal that rhodomyrtone is a new therapeutic agent preventing cancer metastasis.

\section{Acknowledgements}

We would like to thank the Agricultural Research Development Agency (Public Organization), and Office of the Higher Education Commission Thailand.

\section{References}

1. Bravo-Cordero JJ, Hodgson L and Condeelis J: Directed cell invasion and migration during metastasis. Curr Opin Cell Biol 24: 277-283, 2012.
2. Hu YH, Yu LJ, Shao ED, Wu JL and Ji JW: The regulating role of mutant IkappaBalpha in expression of TIMP-2 and MMP-9 in human glioblastoma multiform. Chin Med J (Engl) 122: 205-211, 2009.

3. Figueira RC, Gomes LR, Neto JS, Silva FC, Silva ID and Sogayar MC: Correlation between MMPs and their inhibitors in breast cancer tumor tissue specimens and in cell lines with different metastatic potential. BMC Cancer 9: 20, 2009.

4. Giannelli G, Bergamini C, Marinosci F, Fransvea E, Quaranta M, Lupo L, Schiraldi O and Antonaci S: Clinical role of MMP-2/TIMP-2 imbalance in hepatocellular carcinoma. Int J Cancer 97: 425-431, 2002.

5. Kang JH, Han IH, Sung MK, Yoo H, Kim YG, Kim JS, Kawada T and Yu R: Soybean saponin inhibits tumor cell metastasis by modulating expressions of MMP-2, MMP-9 and TIMP-2. Cancer Lett 261: 84-92, 2008.

6. Lopez-Bergami P, Huang C, Goydos JS, Yip D, Bar-Eli M, Herlyn M, Smalley KS, Mahale A, Eroshkin A, Aaronson S, et al: Rewired ERK-JNK signaling pathways in melanoma. Cancer Cell 11: 447-460, 2007.

7. Crowe DL, Tsang KJ and Shemirani B: Jun N-terminal kinase 1 mediates transcriptional induction of matrix metalloproteinase 9 expression. Neoplasia 3: 27-32, 2001.

8. Shukla S, Maclennan GT, Hartman DJ, Fu P, Resnick MI and Gupta S: Activation of PI3K-Akt signaling pathway promotes prostate cancer cell invasion. Int J Cancer 121: 1424-1432, 2007.

9. Chen PN, Hsieh YS, Chiou HL and Chu SC: Silibinin inhibits cell invasion through inactivation of both PI3K-Akt and MAPK signaling pathways. Chem Biol Interact 156: 141-150, 2005.

10. Kwon GT, Cho HJ, Chung WY, Park KK, Moon A and Park JH: Isoliquiritigenin inhibits migration and invasion of prostate cancer cells: Possible mediation by decreased JNK/AP-1 signaling. J Nutr Biochem 20: 663-676, 2009.

11. Lee SJ, Park SS, Lee US, Kim WJ and Moon SK: Signaling pathway for TNF-alpha-induced MMP-9 expression: Mediation through p38 MAP kinase, and inhibition by anti-cancer molecule magnolol in human urinary bladder cancer 5637 cells. Int Immunopharmacol 8: 1821-1826, 2008.

12. Westermarck J and Kähäri VM: Regulation of matrix metalloproteinase expression in tumor invasion. FASEB J 13: 781-792, 1999.

13. Valastyan S and Weinberg RA: Tumor metastasis: Molecular insights and evolving paradigms. Cell 147: 275-292, 2011.

14. Panthong A, Kanjanapothi D and Taylor WC: Ethnobotanical review of medicinal plants from Thai traditional books, Part I: Plants with anti-inflammatory, anti-asthmatic and antihypertensive properties. J Ethnopharmacol 18: 213-228, 1986.

15. Panthong A, Kanjanapothi D, Taesotikul T and Taylor WC: Ethnobotanical review of medicinal plants from Thai traditional books, Part II: Plants with antidiarrheal, laxative and carminative properties. J Ethnopharmacol 31: 121-156, 1991.

16. Shankar S, Kumar D and Srivastava RK: Epigenetic modifications by dietary phytochemicals: Implications for personalized nutrition. Pharmacol Ther 138: 1-17, 2013.

17. Dachriyanus S, Sargent MV, Skelton BW, Soediro I, Sutisna M, White $\mathrm{AH}$ and Yulinah E: Rhodomyrtone, an antibiotic from Rhodomyrtus tomentosa. Aust J Chem 55: 229-232, 2002.

18. Saising J, Hiranrat A, Mahabusarakam W, Ongsakul M and Voravuthikunchai SP: Rhodomyrtone from Rhodomyrtus tomentosa (Aiton) Hassk. as a natural antibiotic for staphylococcal cutaneous infections. J Health Sci 54: 589-595, 2008.

19. Limsuwan S and Voravuthikunchai SP: Boesenbergia pandurata (Roxb.) Schltr., Eleutherine americana Merr. and Rhodomyrtus tomentosa (Aiton) Hassk. as antibiofilm producing and antiquorum sensing in Streptococcus pyogenes. FEMS Immunol Med Microbiol 53: 429-436, 2008.

20. Limsuwan S, Trip EN, Kouwen TR, Piersma S, Hiranrat A, Mahabusarakam W, Voravuthikunchai SP, van Dijl JM and Kayser O: Rhodomyrtone: A new candidate as natural antibacterial drug from Rhodomyrtus tomentosa. Phytomedicine 16: 645-651, 2009.

21. Sianglum W, Srimanote P, Wonglumsom W, Kittiniyom K and Voravuthikunchai SP: Proteome analyses of cellular proteins in methicillin-resistant Staphylococcus aureus treated with rhodomyrtone, a novel antibiotic candidate. PLoS One 6: e16628, 2011.

22. Srisuwan S, Tongtawe P, Srimanote P and Voravuthikunchai SP: Rhodomyrtone modulates innate immune responses of THP-1 monocytes to assist in clearing methicillin-resistant Staphylococcus aureus. PLoS One 9: e110321, 2014. 
23. Chorachoo J, Saeloh D, Srichana T, Amnuaikit T, Musthafa KS, Sretrirutchai S and Voravuthikunchai SP: Rhodomyrtone as a potential anti-proliferative and apoptosis inducing agent in HaCaT keratinocyte cells. Eur J Pharmacol 772: 144-151, 2016.

24. Scherer D and Kumar R: Genetics of pigmentation in skin cancer - a review. Mutat Res 705: 141-153, 2010.

25. Rigel DS: Cutaneous ultraviolet exposure and its relationship to the development of skin cancer. J Am Acad Dermatol 58 (Suppl 2): S129-S132, 2008.

26. Afaq F: Natural agents: Cellular and molecular mechanisms of photoprotection. Arch Biochem Biophys 508: 144-151, 2011.

27. Bowden GT: Prevention of non-melanoma skin cancer by targeting ultraviolet-B-light signalling. Nat Rev Cancer 4: 23-35, 2004.

28. Lee YC, Lin HH, Hsu CH, Wang CJ, Chiang TA and Chen JH: Inhibitory effects of andrographolide on migration and invasion in human non-small cell lung cancer A549 cells via down-regulation of PI3K/Akt signaling pathway. Eur J Pharmacol 632 23-32, 2010.

29. Okada N, Ishida H, Murata N, Hashimoto D, Seyama Y and Kubota S: Matrix metalloproteinase-2 and -9 in bile as a marker of liver metastasis in colorectal cancer. Biochem Biophys Res Commun 288: 212-216, 2001

30. Waas ET, Wobbes T, Lomme RM, DeGroot J, Ruers T and Hendriks T: Matrix metalloproteinase 2 and 9 activity in patients with colorectal cancer liver metastasis. Br J Surg 90: 1556-1564, 2003 .

31. Guruvayoorappan C and Kuttan G: Amentoflavone inhibits experimental tumor metastasis through a regulatory mechanism involving MMP-2, MMP-9, prolyl hydroxylase, lysyl oxidase, VEGF, ERK-1, ERK-2, STAT-1, NM23 and cytokines in lung tissues of C57BL/6 mice. Immunopharmacol Immunotoxicol 30: 711-727, 2008

32. Liao YC, Shih YW, Chao CH, Lee XY and Chiang TA: Involvement of the ERK signaling pathway in fisetin reduces invasion and migration in the human lung cancer cell line A549. J Agric Food Chem 57: 8933-8941, 2009.

33. Liew K, Yong PV, Lim YM, Navaratnam V and Ho AS 2-Methoxy-1,4-Naphthoquinone (MNQ) suppresses the invasion and migration of a human metastatic breast cancer cell line (MDA-MB-231). Toxicol In Vitro 28: 335-339, 2014.

34. Wang N, Zhu M, Tsao SW, Man K, Zhang Z and Feng Y: Up-regulation of TIMP-1 by genipin inhibits MMP-2 activities and suppresses the metastatic potential of human hepatocellular carcinoma. PLoS One 7: e46318, 2012.

35. Wang ZD, Huang C, Li ZF, Yang J, Li BH, Liang RR, Dai ZJ and Liu ZW: Chrysanthemum indicum ethanolic extract inhibits invasion of hepatocellular carcinoma via regulation of MMP/TIMP balance as therapeutic target. Oncol Rep 23: 413-421, 2010

36. Liao CL, Lai KC, Huang AC, Yang JS, Lin JJ, Wu SH, Gibson Wood W, Lin JG and Chung JG: Gallic acid inhibits migration and invasion in human osteosarcoma U-2 OS cells through suppressing the matrix metalloproteinase-2/-9, protein kinase $\mathrm{B}$ (PKB) and PKC signaling pathways. Food Chem Toxicol 50: $1734-1740,2012$
37. Lu CC, Yang JS, Chiang JH, Hour MJ, Amagaya S, Lu KW, Lin JP, Tang NY, Lee TH and Chung JG: Inhibition of invasion and migration by newly synthesized quinazolinone MJ-29 in human oral cancer CAL 27 cells through suppression of MMP-2/9 expression and combined down-regulation of MAPK and AKT signaling. Anticancer Res 32: 2895-2903, 2012.

38. Hwang ES and Lee HJ: Allyl isothiocyanate and its N-acetylcysteine conjugate suppress metastasis via inhibition of invasion, migration, and matrix metalloproteinase-2/-9 activities in SK-Hep 1 human hepatoma cells. Exp Biol Med (Maywood) 231: 421-430, 2006.

39. Hsieh YS, Chu SC, Yang SF, Chen PN, Liu YC and Lu KH: Silibinin suppresses human osteosarcoma MG-63 cell invasion by inhibiting the ERK-dependent c-Jun/AP-1 induction of MMP-2. Carcinogenesis 28: 977-987, 2007.

40. Weng CJ, Chau CF, Hsieh YS, Yang SF and Yen GC: Lucidenic acid inhibits PMA-induced invasion of human hepatoma cells through inactivating MAPK/ERK signal transduction pathway and reducing binding activities of NF-kappaB and AP-1. Carcinogenesis 29: 147-156, 2008.

41. Chen YY, Liu FC, Chou PY, Chien YC, Chang WS, Huang GJ, Wu CH and Sheu MJ: Ethanol extracts of fruiting bodies of Antrodia cinnamomea suppress CL1-5 human lung adenocarcinoma cells migration by inhibiting matrix metalloproteinase-2/9 through ERK, JNK, p38, and PI3K/Akt signaling pathways. Evid Based Complement Alternat Med 2012: 378415, 2012.

42. Chien ST, Lin SS, Wang CK, Lee YB, Chen KS, Fong Y and Shih YW: Acacetin inhibits the invasion and migration of human non-small cell lung cancer A549 cells by suppressing the p38a MAPK signaling pathway. Mol Cell Biochem 350: 135-148, 2011

43. Shieh JM, Cheng TH, Shi MD, Wu PF, Chen Y, Ko SC and Shih YW: $\alpha$-Tomatine suppresses invasion and migration of human non-small cell lung cancer NCI-H460 cells through inactivating FAK/PI3K/Akt signaling pathway and reducing binding activity of NF-kB. Cell Biochem Biophys 60: 297-310, 2011.

44. Qin J, Tang J, Jiao L, Ji J, Chen WD, Feng GK, Gao YH, Zhu XF and Deng R: A diterpenoid compound, excisanin A, inhibits the invasive behavior of breast cancer cells by modulating the integrin $\beta 1 / \mathrm{FAK} / \mathrm{PI} 3 \mathrm{~K} / \mathrm{AKT} / \beta$-catenin signaling. Life Sci 93 : 655-663, 2013

45. Nakagawa $\mathrm{H}$ and Maeda S: Inflammation- and stress-related signaling pathways in hepatocarcinogenesis. World J Gastroenterol 18: 4071-4081, 2012.

46. Yan KH, Lee LM, Yan SH, Huang HC, Li CC, Lin HT and Chen PS: Tomatidine inhibits invasion of human lung adenocarcinoma cell A549 by reducing matrix metalloproteinases expression. Chem Biol Interact 203: 580-587, 2013.

47. Lu MK, Shih YW, Chang Chien TT, Fang LH, Huang HC and Chen PS: $\alpha$-Solanine inhibits human melanoma cell migration and invasion by reducing matrix metalloproteinase-2/9 activities Biol Pharm Bull 33: 1685-1691, 2010. 